\title{
$\left[H^{s} \mathbf{W}\right]$
}

HOCHSCHULE WÄDENSWIL

\section{University of Applied Sciences Wädenswil}

\author{
Marco Bachmann*
}

\begin{abstract}
The University of Applied Sciences Wädenswil offers three courses in Life Sciences and one course in Facility Management. The course in Food Technology is a three-year course. The very applied curriculum culminates in the diploma of Food Engineer FH. Three different specializations can be chosen in the final year: food technology, beverage technology or nutrition. In the field of applied research and development the department works together with industry and with other Universities in Switzerland and in other countries.
\end{abstract}

Keywords: Food and beverage technology · Food evaluation · Food innovation · Logistics and simulation . Quality management and food safety

The University of Applied Sciences Wädenswil is a member of the Zurich Association of Universities of Applied Sciences and offers three study courses in the field of life sciences - Food Technology, Biotechnology, Horticulture - and one course in Facility Management. The studies allow the possibility of different specializations

Table 1

$\begin{array}{llll}\text { Food Technology } & \text { Biotechnology } & \text { Horticulture } & \text { Facility Management } \\ \text { Food Technology } & \text { Biotechnology } & \text { Plant Production } & \text { Real Estate Management } \\ \text { Beverage Technology } & \text { Pharmaceutical } & \text { Plant Design } & \text { Consumer Affairs } \\ & \begin{array}{l}\text { Technology } \\ \text { Nutrition }\end{array} & \text { Process informatics } & \text { Hospitality Management }\end{array}$

Table 2

${ }^{*}$ Correspondence: Dr. M. Bachmann

University of Applied Sciences

Food Technology Department

P.O Box 335

$\mathrm{CH}-8820$ Wädenswil

Tel.: +4117899900

Fax: +4117899950

E-Mail: m.bachmann@hswzfh.ch
(Table 1). Furthermore, the University of Applied Sciences offers graduate courses, research and development, and provision of services.

In the fields of applied research and development the main areas are summarized in Table 2.

Food Technology
Food and beverage design
Food microbiology and quality assurance
Sensory, physical and chemical food analysis
Process informatics
Facility Management
Consumer Affairs
Hospitality Management

\section{Biotechnology}

Molecular biology

Bioprocess engineering

Pharmaceutical technology

Horticulture

Ecological engineering

Plant usage

Trial \& product innovation 


\section{Food Technology at the University of Applied Sciences Wädenswil}

The department of food technology of the University of Applied Sciences Wädenswil first offered this course of study in 1988. It is designed to train students to graduate as Food Engineers $\mathrm{FH}$ and uses the following maxim: 'Preparing people for business'.

To achieve this purpose, the curriculum comprises methods of obtaining, processing, and conserving food for the consumer, taking into account all aspects of logistics, selling, marketing, and quality as well as the relevant legal and operational factors.

\section{Why We Offer This Curriculum}

Food technology will continue to gain in importance worldwide in order to guarantee the planet's food supply. Available resources need to be husbanded responsibly and manufacturing technologies optimized ecologically.

Our three-year curriculum ending with the diploma of Food Engineer FH focuses on the following areas:

- Social competence (independence, communication skills, team spirit, openness to criticism)

- Methodical competence (understanding interdependent trends and developments, systems engineering, experimental design)

- Technical competence in:

- Food manufacturing, beverage technology, functional food, quality control, aspects of the physiology of nutrition

- Planning equipment and processes for food production (food processing technology, automation and process informatics, logistics and simulation, CAD in food plants)

- Food evaluation (chemical, microbiological, physical and sensory analysis)

- Consumption patterns (food legislation and declaration, sensory tests, market acceptance, food and beverage design, consumer behaviour)

- Managing a food manufacturing plant (economics, business management, personnel management)

The Food Engineer FH is the link between university graduates, technical employees, and specialists in all areas of food technology.

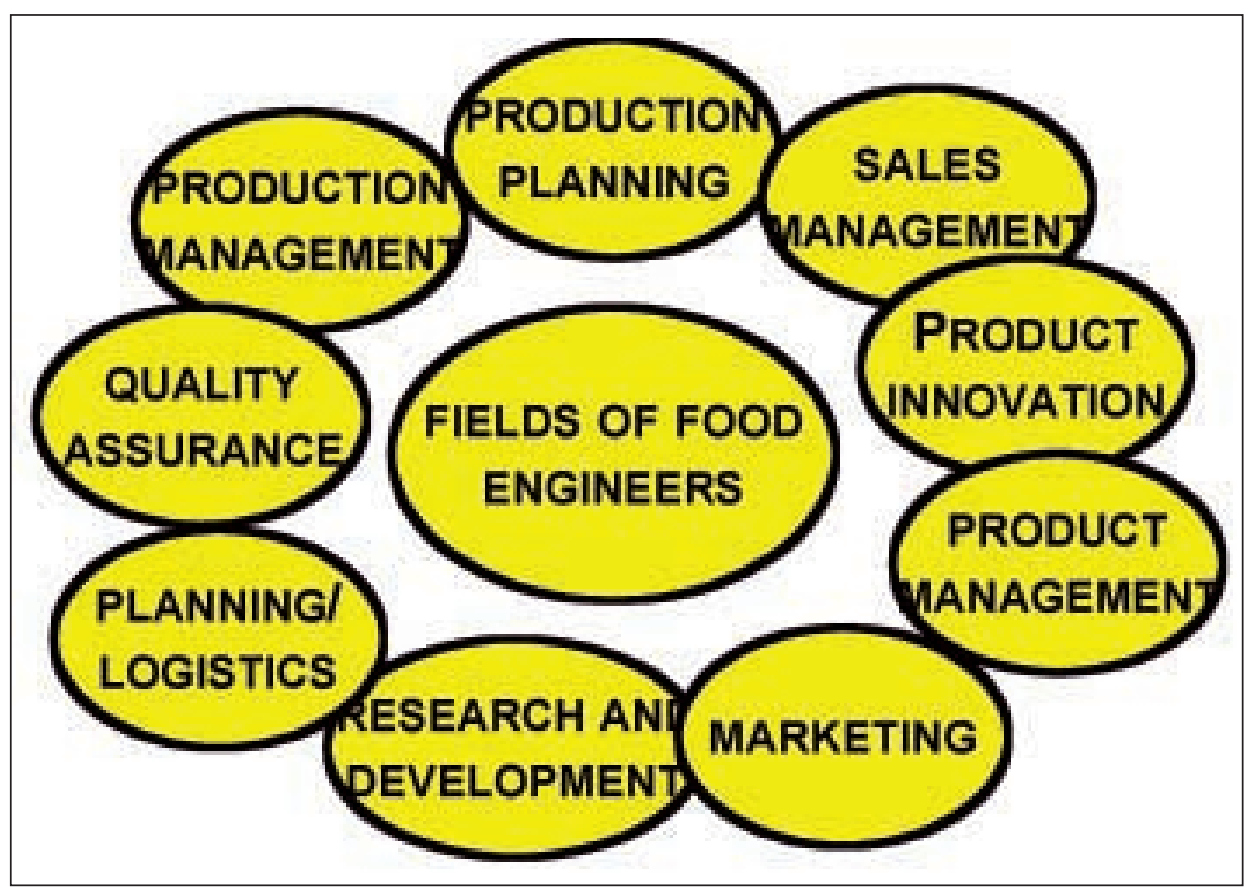

Fig. Professional prospects 